\title{
MENYEMAIKAN KEMAMPUAN MELIHAT DENGAN HATI BAGI MAHASISWA ARSITEKTUR
}

\author{
Linda Octavia $^{1}$, Eko Prawoto ${ }^{2}$ \\ 1,2. Program Studi Arsitektur, Fakultas Arsitektur dan Desain, Universitas Kristen Duta wacana, \\ Jl. dr. Wahidin Sudirohusodo No. 5-25, Yogyakarta \\ Email: ${ }^{1}$ lindaoctavia2010@gmail.com, ${ }^{2}$ ekoprawoto@yahoo.com
}

\begin{abstract}
Abstrak
Perubahan selalu terjadi di dalam alam ini, baik yang berlangsung secara cepat maupun lambat. Perubahan-perubahan mendasar yang terjadi di segala bidang kemudian membawa dampak bagi kehidupan, tidak terkecuali pendidikan arsitektur. Dengan demikian, pendidikan arsitektur juga harus berbenah untuk mengantisipasi persoalan-persoalan besar yang sedang dihadapi. Studio tahun pertama ini merupakan salah satu gagasan perubahan dalam pendidikan arsitektur, yaitu dengan mencoba mencari pondasi yang berbeda, dimana penekanan pendidikan bukan pada akumulasi informasi namun membangun orang yang memiliki kepekaan dan keterampilan untuk berpikir dalam perspektif kebersamaan. Mindful eyes sebenarnya adalah kesadaran untuk melihat, belajar lewat mata secara sadar yang diterapkan pada studio tahun pertama ini, bertujuan untuk belajar mengenali alat-alat belajar yang akan dipakai pada tahapan-tahapan studio tahun berikutnya. Tulisan ini merupakan respon pendidikan arsitektur dalam menghadapi perubahan dan sedang diterapkan pada mahasiswa arsitektur tahun pertama. Beberapa contoh tugas mahasiswa tahun pertama disajikan dengan sangat sederhana, namun mempunyai tujuan untuk mempersiapkan arsitek di masa mendatang dengan beberapa keterampilan yang mendasar.
\end{abstract}

Kata kunci: mindful eyes, pendidikan arsitektur, pondasi pembelajaran, studio tahun pertama.

\begin{abstract}
Title: Developing Mindful Eyes of the Architecture Students

Change is bound to happen in nature, be it revolutionary or evolutionary. The fundamental changes that occur throughtout all aspects would consequently have an impact on life in its entirety, and architecture education is no exception. Hence, architecture education should also continue to refine itself to anticipate the substantial issues it encounters. This first year studio is one of the concepts of change in architecture education, namely by attempting to find a different foundation wherein the emphasis of education is not in the accumulation of information but in fostering individuals to acquire sensitivity and skills for contemplating through a perspective of mutual togetherness. Mindful eyes is actually the consciousness to see, to learn through one's eyes with awareness, which is implemented in this first year studio with the objective of learning to recognize the tools that will be used in the subsequent studios in the following years to come. This paper is the response of architecture education in confronting changes and it is currently implemented on first year architecture students. Several samples of first year student tasks are presented in a very simple manner, it is, however, aimed at preparing future architects with several essential skills.
\end{abstract}

Keywords: mindful eyes, architecture education, foundation of learning, first year studio. 


\section{Pendahuluan}

Tidak ada suatu hal yang tetap di alam ini. Segala sesuatu pasti mengalami perubahan, baik secara perlahan maupun secara cepat. Dengan demikian, jika ada suatu hal yang tetap di alam ini, hal itu adalah perubahan itu sendiri. Herakleitos, seorang Filsuf Yunani mengatakan panta rhei kai uden menei, yaitu semuanya mengalir dan tidak ada sesuatupun yang tinggal tetap.

Perubahan di segala bidang terjadi dengan sangat cepat pada era modern ini. Teknologi informasi berkembang dengan pesat yang tentu saja memiliki dampak pada pendidikan, khususnya pendidikan arsitektur. Tentu saja, pendidikan arsitektur harus berbenah diri dalam menghadapi perubahan yang terus terjadi dan tidak dapat diprediksi kecepatannya. Akan tetapi, seringkali para pendidik enggan untuk keluar dari kemapanan pendidikan arsitektur yang sudah berlangsung lama, sehingga terjadi kecenderungan pengajaran arsitektur yang diberikan kepada mahasiswa saat ini masih menggunakan konteks puluhan tahun silam, dimana persoalan-persoalan yang harus dihadapi sudah berbeda.

Realita yang terjadi saat ini adalah persoalan tentang krisis lingkungan dan juga adanya kemendesakan untuk tindakan nyata. Eiji Uehiro, dalam Practical Ethics of Our Time mengatakan bahwa:

"Now the destruction of nature has become a worldwide problem. Nature has never been damaged to this extent until the last forty or fifty years. During this short period - only an instant in the long history of humankind - we have cruelly crippled our natural environment, and now it is dying before our very eyes".
"We need to realize that the earth is not limitless. The polluted and injured earth is trying to tell us that is does have its limit".

"However, most people seem blind to its agony, and seek comfort by clinging to the illusion that nature is limitless or at least large enough to take care of itself".

Kesadaran diri tentang sangat terbatasnya alam sangat diperlukan. Hal ini akan sangat menentukan bagaimana cara kita bersikap dan bertindak dalam kehidupan sehari-hari, khususnya yang berkaitan dengan profesi sebagai arsitek. Pendidikan arsitektur seharusnya dapat mengambil peran dalam hal ini melalui perubahan kurikulum pendidikannya, sehingga pendidikan arsitektur saat ini dapat memiliki kontribusi penting dalam mengantisipasi persoalan-persoalan besar yang sudah terjadi dan akan terjadi, termasuk masalah krisis lingkungan.

Tulisan ini bertujuan untuk memaparkan bagaimana respon pendidikan arsitektur dalam menghadapi dan mengantisipasi perubahan. Hal-hal sesehari tentang alam digunakan sebagai pendekatan (sarana belajar) untuk mengenali alatalat belajar, juga melatih kepekaan tubuh kita untuk belajar dengan sadar.

\section{Metode}

Metode yang digunakan dalam kajian ini adalah 'belajar dari alam'. Seperti yang dilakukan Mangunwijaya (1988) dalam tulisannya di Wastu Citra untuk menjelaskan konsep tentang citra. Bentukan lumbung padi Minang memiliki bentuk dan gaya bahasa yang laras dengan alam sekitarnya yang merupakan pegunungan dan juga seperti pohon semakin melebar ke atas. 


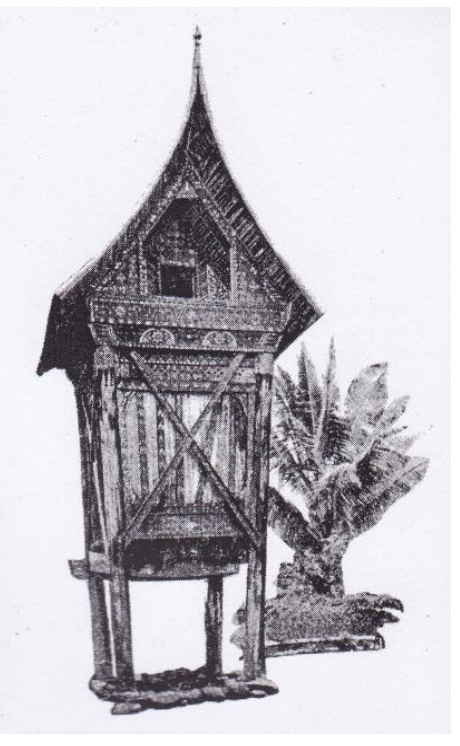

Gambar 1. Lumbung padi Minang disandingkan dengan pohon yang semakin melebar ke atas

Sumber: Mangunwijaya, 1988, hal.31

Selain itu, Mangunwijaya juga mengatakan bahwa:

"Lembah sawah atau bentuk sungai, pantai dan pepohonan, ombak-ombak kuala dan awan serta biru angkasa, semua itu logis. Lereng-lereng membentuk ruang-ruang yang meyakinkan, citra manusia yang bekerja secara benar".

(Mangunwijaya, 1988, hal. 331).

Berdasarkan penjelasan tersebut, maka logika yang diajarkan oleh alam, diterapkan di dalam desain arsitektur. Kesadaran ini harus ditanamkan kepada mahasiswa sejak dini karena ini merupakan kesadaran dasar yang akan berpengaruh ketika mereka suatu saat nanti menjadi arsitek.

\section{Hasil dan Pembahasan}

Studio Arsitektur Tahun Pertama: Mencoba Mencari Pondasi yang Berbeda

Studio tahun pertama ini diposisikan sebagai dasar pembelajaran dan sebagai pijakan untuk studio-studio berikutnya. Pada tahun pertama penting untuk memberikan pemahaman tentang bagaimana belajar, bukan sekadar tahu tentang apa yang dipelajari. Cara belajar menjadi penekanan penting dalam studio tahun pertama ini. Jadi, penekanan pendidikan bukan pada akumulasi informasi namun membangun kemampuan atau kesadaran mahasiswa untuk memiliki kepekaan dan keterampilan untuk berpikir dalam perspektif kebersamaan.

Belajar melihat dengan sangat pelan diperlukan dalam situasi ini. Lalu, mengapa diperlukan melihat dengan pelan padahal di era modern ini kita dituntut untuk melakukan segala sesuatu dengan sangat cepat? Ternyata, ada banyak hal yang terlewat ketika kita terbiasa melihat dengan cepat. Melihat dengan pelan ini dimaksudkan agar kita memiliki perhatian lebih pada hal-hal kecil di sekeliling kita yang pada akhirnya akan menumbuhkan kepekaan dan empati yang tinggi dalam melihat dan bertindak secara nyata.

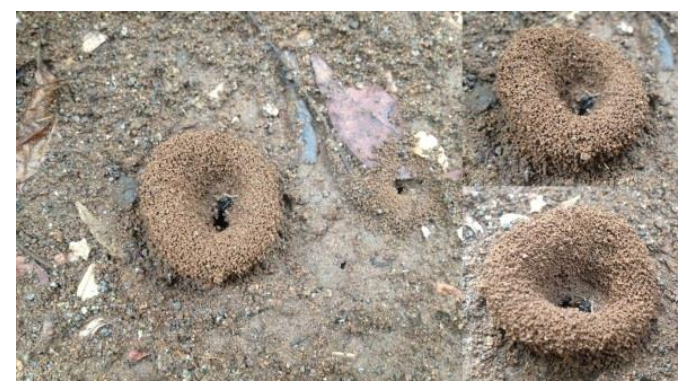

Gambar 2. Rumah semut yang jarang kita perhatikan

Sumber: Dokumentasi Octavia, 2016 


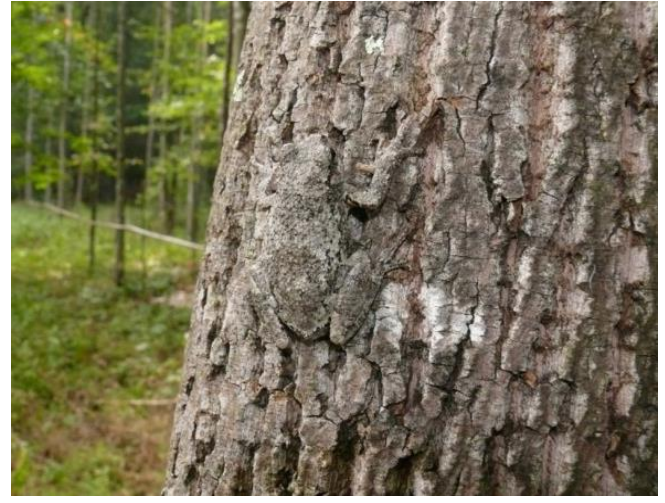

Gambar 3. Kulit pohon yang seringkali dianggap 'biasa'

Sumber: Dokumentasi Octavia, 2016

Rumah semut dan kulit pohon di atas merupakan contoh hal-hal yang sangat visual dan seringkali terlupakan atau terlewat begitu saja. Namun, dalam studio tahun pertama ini, hal-hal sesehari yang 'biasa' tadi, diperhatikan dengan lebih detail yang berguna untuk melatih agar tubuh kita belajar dengan sadar dengan menggunakan kelima panca indera sebagai interface dengan sekitar.

Dalam pendidikan arsitektur, pada tahun pertama merupakan tahap pengenalan diri dengan menyiapkan 'alat' belajar yaitu lima indera. Tahun kedua merupakan interrelasi diri dengan sekitarnya. Sedangkan tahun ketiga ada dinamika yang lebih kompleks dirinya dengan masyarakat dan sekitarnya.

Studio tahun pertama ini mempunyai peran untuk mempersiapkan potensi diri, memahami sekitar melalui interaksi dengan diri sendiri, juga melalui pertemuan diri sendiri dengan alam. Dengan demikian, pada tahapan ini, bukanlah bertumpu pada informasi atau ilmu sebanyak-banyaknya, tetapi sikap nilai juga diutamakan.

Permasalahan yang diakibatkan oleh perubahan-perubahan mendasar di dunia ini harus dihadapi untuk mempersiapkan arsitek di masa mendatang, dengan berbagai keterampilan yang harus dimiliki secara mendasar, yaitu:

1. Kesadaran dan kemampuan hidup harmonis dengan alam sebagai kesadaran spiritual,

2. Arsitek yang mampu berpikir terintegrasi dan tidak parsial, hanya sepotong-sepotong saja,

3. Bersikap inklusif, empati dan emansipatoris juga berwawasan sosial.

Dengan berkembangnya pengetahuan yang berkait dengan arsitektur sebenarnya ada banyak sekali tersedia temuan serta inovasi kreatif yang bisa dipakai untuk menyelesaikan masalah kehidupan. Disini, kepekaan memahami konteks menjadi sangat penting. Konteks dalam artian yang luas, yaitu iklim, sosial budaya dan juga lingkungan serta kehidupan manusianya. Sehingga, titik berat pemikiran seharusnya diberikan pada terwujudnya arsitektur yang melayani kehidupan yang harmonis dengan alam.

Bagaimana menyelenggarakan pendidikan yang demikian? Pembenahan pendidikan arsitektur perlu dilakukan, yaitu dengan melakukan pembenahan kecil, mulai dari yang paling ujung, yaitu pembelajaran arsitektur di tahun pertama ini. Kembali ke alam merupakan salah satu pendekatan yang dilakukan dalam studio tahun pertama, dengan tujuan tahap pertama adalah mengenalkan mahasiswa tentang bahasa bentuk yang ada di alam dan unsur-unsurnya; tahap kedua mengenalkan tentang elemen-elemen bentuk yang lain, seperti geometri, organisasi atau tatanan bentuk, struktur, tekstur dan warna, dan 
sebagainya. Kemudian, tahap ketiga adalah mengenalkan tentang logika bentuk. Tahapan-tahapan belajar juga media pembelajaran yang dipakai ini bertujuan untuk mencapai kompetensi yang akan dibangun sebagai bekal untuk arsitek-arsitek di masa mendatang.

\section{Kembali ke Alam}

Alam merupakan karunia yang sangat luar biasa dari Sang Pencipta yang dapat kita manfaatkan sebagai laboratorium untuk belajar banyak hal di dalamnya. Namun, hal ini seringkali tidak kita sadari dan sering terlewat begitu saja. Lalu, bagaimanakah cara kita untuk belajar dari alam? Belajar dari alam dapat kita lakukan ketika kita melihat dengan lebih pelan dengan menggunakan hati dan mata kita.

Di dalam Wastu Citra, Mangunwijaya mengatakan bahwa:

"Menciptakan arsitektur adalah memanfaatkan dan mengangkat martabat alam. Menurut kebutuhan dan situasi kondisi. Kita dapat belajar dari alam itu sendiri dan pengolahan alam itu oleh para petani dan mereka yang justru tidak berniat langsung eksplisit membuat arsitektur".

(Mangunwijaya, 1988, hal.331)

Tulisan tersebut dengan jelas menunjukkan bahwa membuat arsitektur harus respek terhadap alam baik secara keseluruhan maupun sampai kepada hal-hal yang sangat mendetail, misalnya sisa tetesan air hujan pada daun adalah salah satu hal yang jarang kita perhatikan. Namun, jika dilihat dengan detail, maka akan ada sesuatu yang istimewa, tentang bagaimana air yang merupakan benda cair membentuk sebuat butiran, bulat seperti bola yang menempel maupun menggantung pada ujung-ujung daun dalam kurun waktu tertentu. Hal ini bisa terjadi karena partikel-partikel air saling terik-menarik ke dalam, karena resultan di permukaan zat cair itu tidak sama dengan nol, maka partikelpartikelnya jadi tertarik ke bawah.

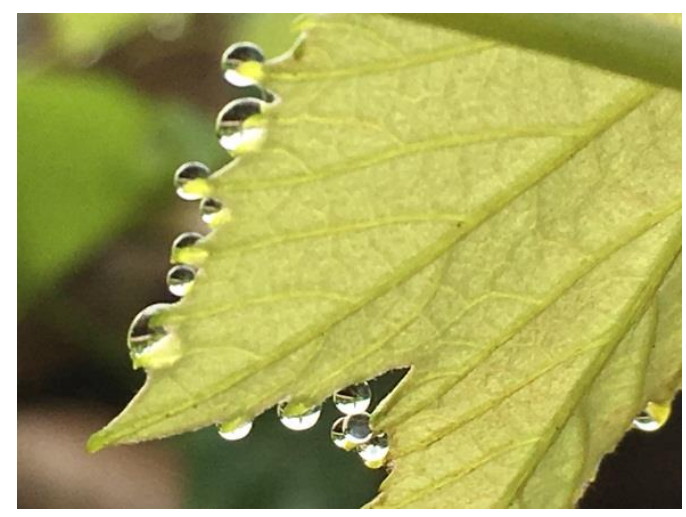

Gambar 4. Tetesan embun berbentuk bola menempel pada ujung-ujung daun Sumber: Dokumentasi Prawoto, 2016

\section{Geometri}

Ketika kita melihat tanaman-tanaman ini dengan lebih teliti dan detail, akan terlihat unsur geometri yang terbentuk dengan sempurna dari alam itu sendiri. Alam merupakan sumber inspirasi geometri yang tiada habisnya. Misalnya saja bentuk lingkaran yang kita ambil dari matahari atau bulan. Terlebih lagi tanaman, kita bisa mendapatkan ide geometri yang lebih melimpah. Katakan saja penampang buah belimbing yang membentuk bintang dengan lima sudut, atau daun waru yang memberi inspirasi bentuk 'love'. Jika 'kepekaan' terhadap geometri ini terus diasah, maka mahasiswa bisa mendapatkan bentukan-bentukan 'baru' yang mungkin tidak pernah terbayangkan sebelumnya.

Misalnya pada gambar 5 ini, sebuah kelopak yang terdiri dari lapisanlapisan 'segitiga' sebagai sebuah 'gradasi' geometris. Bagian pusatnya adalah bagian tunas yang paling lemah, 
yang makin keluar makin besar sekaligus sebagai pelingkupnya. Bentuk konsentris ini bukan mengadaada atau asal ada, tetapi sebagai sebuah bentuk 'pertahanan diri' agar tunas yang lemah itu tetap terlindungi di bagian tengahnya. Apalagi masih ditambah dengan adanya duri yang tajam di setiap ujung segitiga, yang serupa 'tombak penjaga' bagi proses tumbuh kembang tanaman itu. Jadi, disini tidak hanya belajar tentang geometri, tetapi juga logika di baliknya, tentang mengapa geometri itu yang muncul.

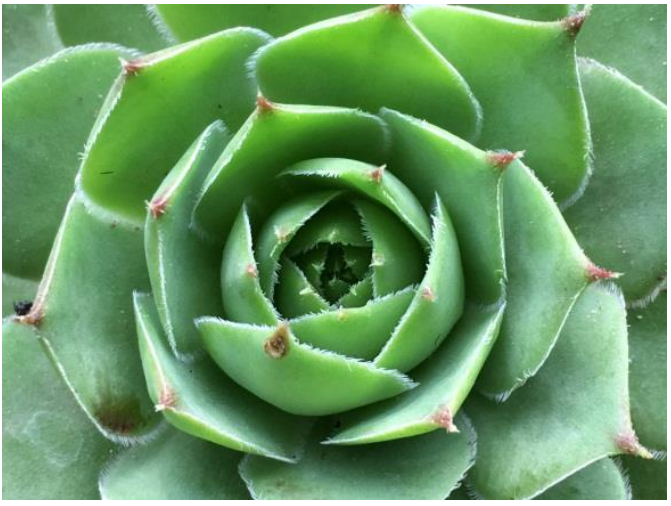

Gambar 5. Kelopak yang terdiri dari lapisan-lapisan 'segitiga' sebagai sebuah 'gradasi' geometris

Sumber: Dokumentasi Prawoto, 2016

Lalu, bentuk sulur-suluran yang merupakan tunas tanaman pakis, ini adalah bentuk busur yang melingkar, yang semakin ke ujung semakin kecil diameter lingkarannya. Disini juga terjadi proses, tunas yang awalnya memiliki diameter kecil, akan terus tumbuh dan menjadi bentuk sulur yang semakin lebar diameternya, sampai pada akhirnya menjadi bentuk daun yang sempurna. Dengan memahami pergerakan seperti itu, bisa diterapkan ke dalam arsitektur, mungkin dalam bentuk kinetic architecture, atau lainnya.

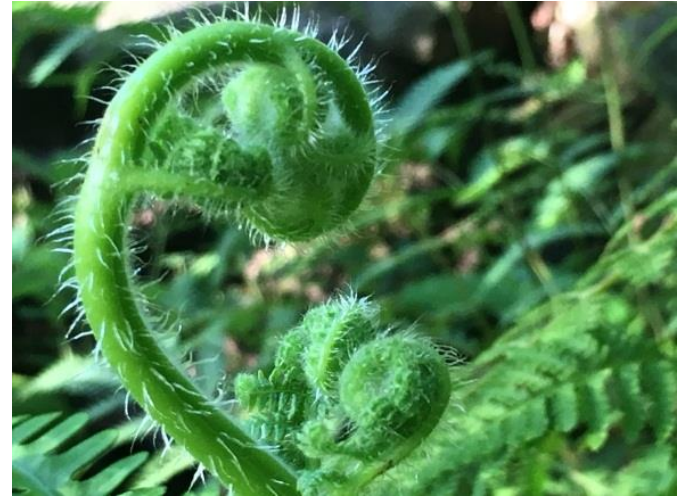

Gambar 6. Tunas tanaman Pakis sebagai bentuk busur melingkar

Sumber: Dokumentasi Prawoto, 2016

\section{Organisasi atau Tatanan}

Organisasi atau tatanan juga dapat kita temukan dengan belajar dari alam. Alam memberi inspirasi bagaimana kita mengorganisasi sesuatu, entah ruang, bentuk ataupun struktur. Misalnya saja pada hutan hujan tropis, bagaimana pohon-pohon besar membentuk kanopi yang "melindungi" tanaman-tanaman dan bahkan binatang di bawahnya, membentuk sebuah tatanan bahwa pohon besar sebagai penaung, sementara pohon-pohon yang lebih kecil sebagai penghuni di bawah kanopi dengan suhu yang lebih nyaman, maka muncullah pakupakuan, anggrek hingga lumut di dalamnya.

Dari susunan tulang daun, mahasiswa bisa belajar tentang tatanan mulai dari tulang daun utama yang di tengah sebagai axis, lalu ada tulang-tulang daun yang lebih kecil sebagai percabangannya, dan demikian seterusnya sampai ke tulang daun yang paling kecil. Sebuah logika bagaimana menata bagian demi bagian secara "masuk akal" dan bisa diterima oleh gerak semesta. 


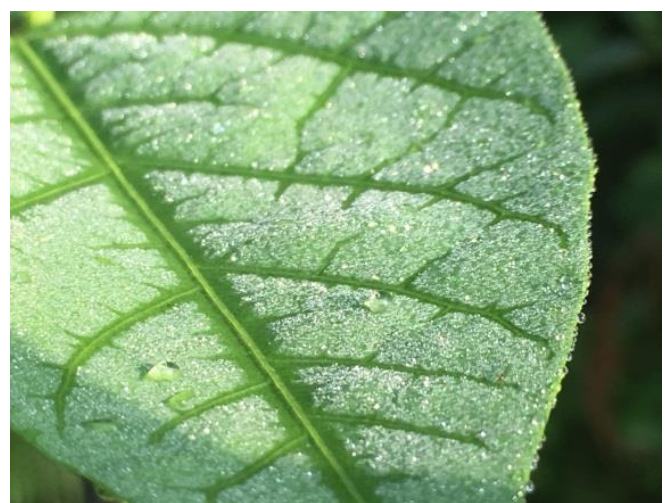

Gambar 7. Susunan tulang daun dengan tatanan yang memiliki axis

Sumber: Dokumentasi Prawoto, 2016

Dalam kasus lainnya, mahasiswa juga bisa belajar pada susunan daun kecilkecil yang berirama ritmik, yang ditata secara berurutan dengan bentukan yang kurang lebih sama. Sebuah tatanan yang berulang. Meskipun berulang, tetapi jika diamati secara lebih seksama, sebenarnya bentuk daun-daun kecil itu tidaklah sama persis, tetapi memang hampir sama. Tarikan antara yang sama dan yang hampir sama ini membentuk logika dasar dalam tatanan alam: bahwa alam tidak pernah melahirkan dua spesies atau individu yang sama persis, karena alam memang bukan pabrik.

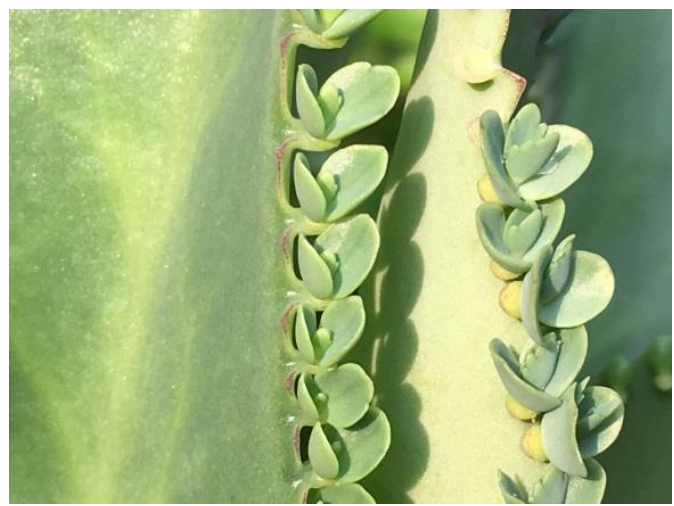

Gambar 8. Susunan daun kecil yang berirama ritmik

Sumber: Dokumentasi Prawoto, 2016

\section{Struktur}

Struktur merupakan hal yang sangat vital dalam arsitektur, yang secara sederhana bisa didefinisikan sebagai sarana untuk menyalurkan beban baik itu beban akibat dari penggunaan ataupun kehadiran bangunan itu sendiri - ke dalam tanah.

Dari alam, kita bisa belajar banyak tentang struktur. Sebagai contoh, pohon kelapa di pantai yang bisa berdiri kokoh pada tanah yang berpasir, sementara beban pohon kelapa itu sendiri cenderung berat di bagian atas. Ternyata, kuncinya terletak pada konstruksi akarnya yang berupa akar serabut yang mampu mencengkeram tanah tempat tumbuhnya. Hal ini juga yang mengilhami Ir. Sedijatmo untuk membuat pondasi cakar ayam yang mampu mencengkeram tanah di tempat berdirinya bangunan.

Disini mahasiswa juga bisa belajar hal semacam itu, dengan melihat objekobjek alam yang lain dan mempelajari bagaimana strukturnya. Salah satunya jamur, yang mampu tumbuh di permukaan kulit pohon. Bentuknya yang unik (tidak konvensional) bisa memberikan rangsangan kepada mahasiswa agar berpikir bagaimana struktur semacam itu bisa berdiri. Tentunya bagian akarnya (pondasinya) berupa akar yang mencengkeram kulit pohon, sebagai syarat agar tidak kolaps. Bagian batangnya yang berwarna coklat sebagai struktur tengah atau kolom yang lebih keras dibanding kanopinya. Akhirnya, bagian paling atas adalah kanopi yang berupa membran tipis melebar seperti payung yang melebar, yang "dipegang" oleh kolom. 
Dengan logika struktur seperti ini, mahasiswa bisa belajar strukturstruktur alternatif agar tak hanya tahu struktur yang "aman" saja. Eksplorasi desain dalam kasus tertentu juga berarti eksplorasi struktur, karena struktur adalah hal vital sebagai syarat kokoh saja, tetapi sekaligus juga anggun dan estetis seperti jamur di permukaan kulit pohon ini.

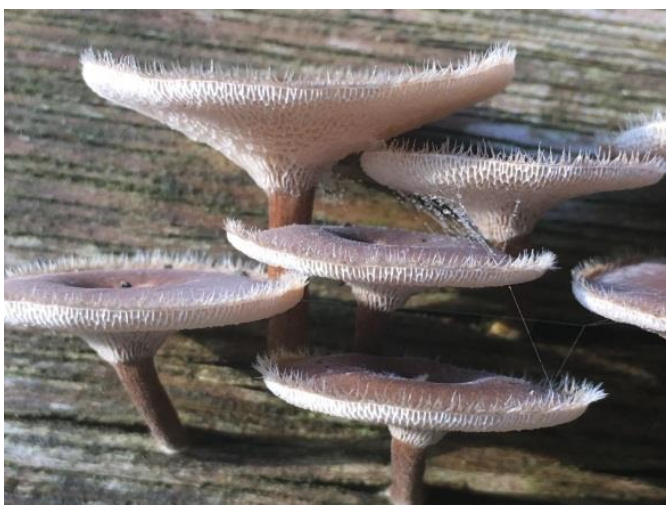

Gambar 9. Jamur yang tumbuh pada permukaan kulit pohon

Sumber: Dokumentasi Prawoto, 2016

Daun juga memiliki struktur yang serupa, memiliki tangkai sebagai pemegang membran daun. Tangkai inipun memiliki hierarki, yang paling besar sebagai tangkai utama daun yang menempel pada ranting. Tangkai ini kemudian bercabang membentuk semacam tulangan yang lebih kecil pada daun, sekaligus sebagai penguat membran daun agar lebih "kaku". Lalu, masih ada tulangan yang lebih kecil lagi yang membentuk jaringan yang saling terhubung, demikian seterusnya. Dari selembar daun yang kecil, kita bisa belajar tentang struktur, tentang arah dan pembagian pembebanan yang tepat.

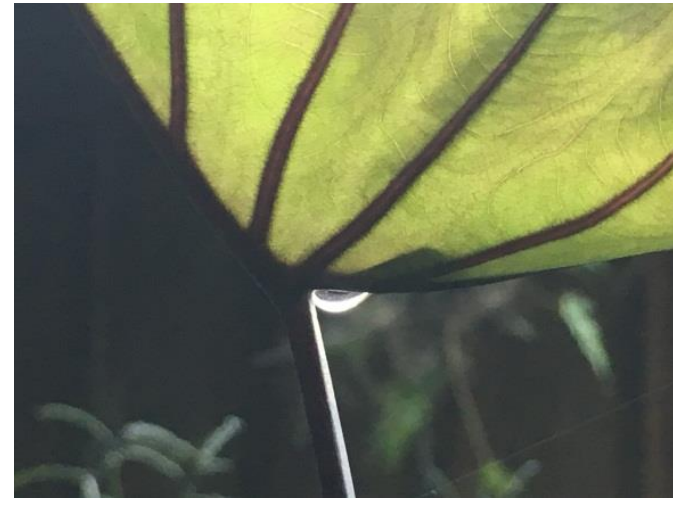

Gambar 10. Struktur daun: tangkai sebagai pemegang membran daun

Sumber: Dokumentasi Prawoto, 2016

\section{Tekstur dan Warna}

Tekstur dan warna merupakan salah satu hal yang mendasar untuk dipahami mahasiswa arsitektur. Alam juga merupakan sumber warna yang tak kalah hebatnya. Yang jelas, tidak hanya warna hijau saja yang dimiliki alam, tetapi ada banyak warna lain yang bisa dieksplorasi. Warna yang paling "lengkap" mungkin dimiliki oleh pelangi, didalamnya mengandung gradasi warna mulai dari merah sampai ungu. Bahkan, ada banyak cerita atau legenda berkaitan dengan adanya pelangi ini, yang antara daerah satu dan lainnya memiliki cerita yang berbeda-beda, biasanya ceritanya berhubungan dengan alam dunia dan alam atas (kahyangan).

Seperti pada contoh ini, daun juga memiliki warna yang bermacam-macam, bahkan dari satu daun bisa memunculkan beberapa variasi warna yang berbedabeda. Ada coklat, krem, kuning sampai ungu, dengan gradasi dan komposisi yang bisa dibilang advance. Jika kita lebih berani dan lebih dalam ketika berinteraksi dengan alam, maka alam pun akan memberikan "rahasia-rahasianya" yang tersembunyi kepada kita. 


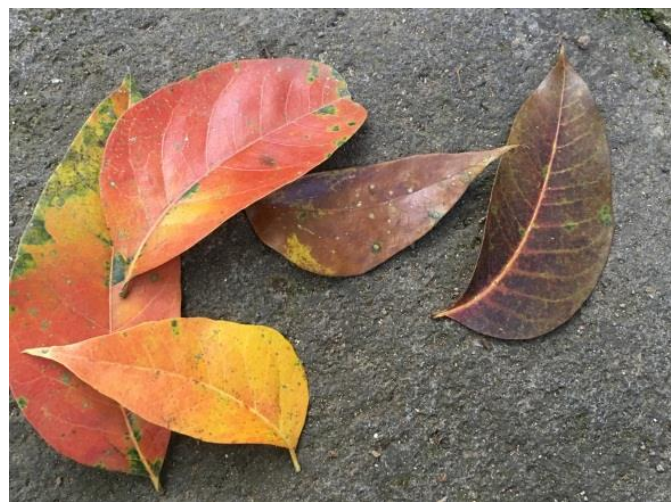

Gambar 11. Gradasi warna pada daun Mahoni Sumber: Dokumentasi Prawoto, 2016

Warna binatang juga seringkali menarik, seperti serangga dengan warna yang mengkilap ini. Bahwa warna metalik yang kita kenal saat ini sebetulnya sudah sangat purba umurnya, dan itu menunjukkan bahwa alam memang selalu kontekstual, hanya kita saja yang harus pandai dalam mengamatinya secara lebih intens.

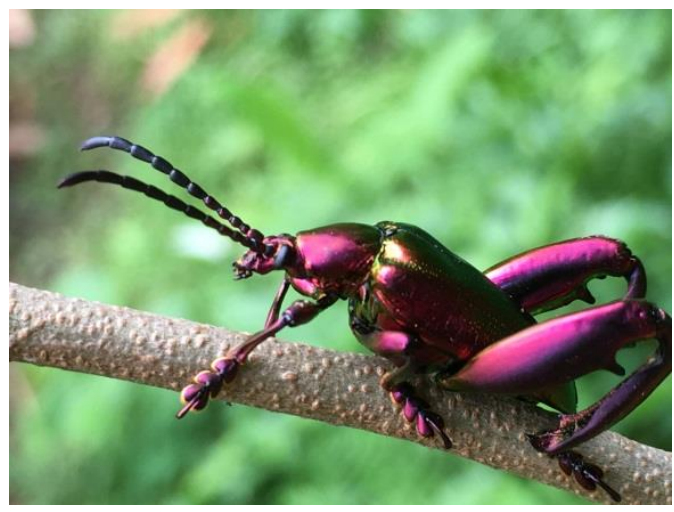

Gambar 12. Serangga dengan warna mengkilap

Sumber: Dokumentasi Prawoto, 2016

\section{Aktivitas}

Aktivitas adalah salah satu penanda kehidupan di alam, terutama yang dilakukan binatang. Tidak harus binatang yang besar, bahkan pada binatang kecil seperti semut-semut ini kita bisa belajar tentang aktivitas, tentang pembagian kerja dan tentang displin. Semut merupakan salah satu binatang yang memiliki organisasi yang sangat teratur, memiliki ratu sebagai sentral kehidupan mereka, lalu ada juga semut pekerja dan juga semut tentara, masing-masing mempunyai pembagian tugas yang jelas. Ini sebagai contoh dari masyarakat pekerja-profesional yang rapi.

Mungkin bukan hanya masalah kerja atau aktivitas belaka, tetapi tentang kehidupan sosial. Selama ini, manusia juga dianggap sebagai makhluk sosial, tetapi sisi sosialnya semakin lama semakin terkikis di tengah kehidupan kota yang penuh dengan persaingan. Sikap individualistik manusia itulah yang menjadi bibit awal kegagalan sebuah kota. Dalam hal ini, kita bisa belajar banyak hal dari semutsemut ini.

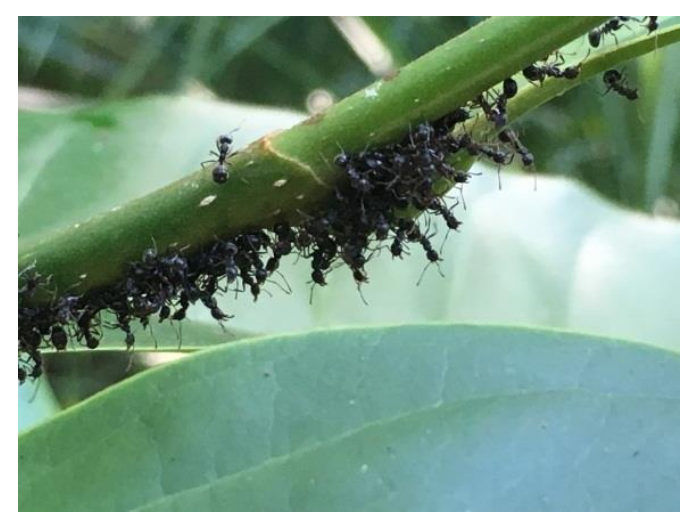

Gambar 13. Aktivitas semut pada sebuah tangkai

Sumber: Dokumentasi Prawoto, 2016

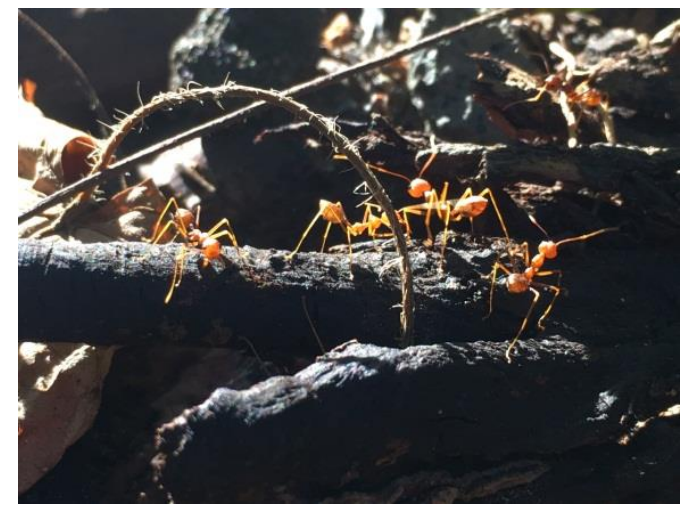

Gambar 14. Aktivitas semut merah pada batang pohon

Sumber: Dokumentasi Prawoto, 2016 


\section{Kreativitas dan Kecerdasan}

Alam juga menyimpan kecerdasan yang "lain", yang tidak habis untuk digali dari masa ke masa. Bukanlah sebuah hal yang harus dipertanyakan tentang dari mana mereka mendapatkan kemampuan kreatif seperti itu, tetapi yang lebih penting adalah bagaimana-nya. Bagaimana mereka mampu membuat terobosan yang cerdik ketika hidup di alam yang penuh "bahaya" dan "ancaman".

Tentang kamuflase adalah hal yang menarik, ketika binatang-binatang berusaha mengelabuhi musuhnya dengan beragam cara. Contohnya adalah belalang sembah (praying mantis) ini. Ketika hinggap diantara bunga dan dedaunan, belalang ini dapat menyamarkan bentuknya sehingga menjadi seperti bunga atau daun dengan tujuan untuk melindungi dirinya dari tangkapan musuh. Kamuflase menjadi hal yang penting pula dalam arsitektur, terutama berhubungan dengan arsitektur pertahanan atau militer, juga fasilitasfasilitas penting lainnya agar tidak terlihat oleh lawan yang ingin menghancurkannya.

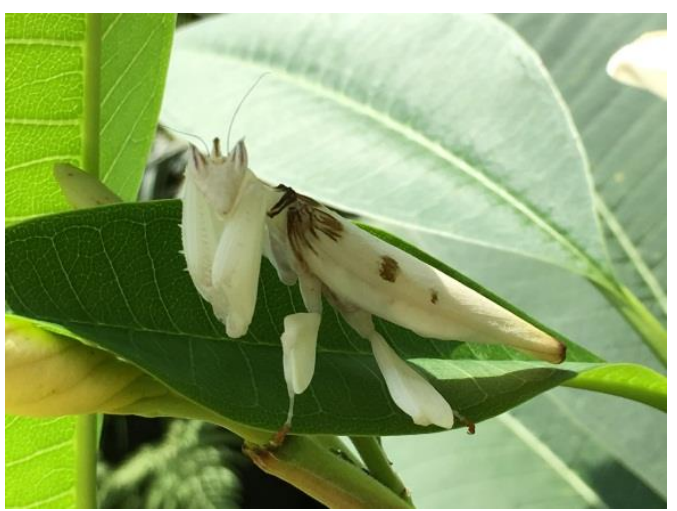

Gambar 15. Belalang sembah sedang berkamuflase ketika hinggap di dedaunan Sumber: Dokumentasi Prawoto, 2016

Kecerdasan laba-laba dengan sarangnya yang unik ini memiliki banyak kegunaan. Laba-laba ini menjebak mangsa dengan rumahnya itu dan sekaligus juga memberikan nilai estetis dan fungsional. Bentuknya yang dibuat radial, dari bahan semacam benang yang diproduksi dari tubuhnya sendiri. Hal ini merupakan sebuah penyatuan antara rumah dan pemilik yang tiada duanya.

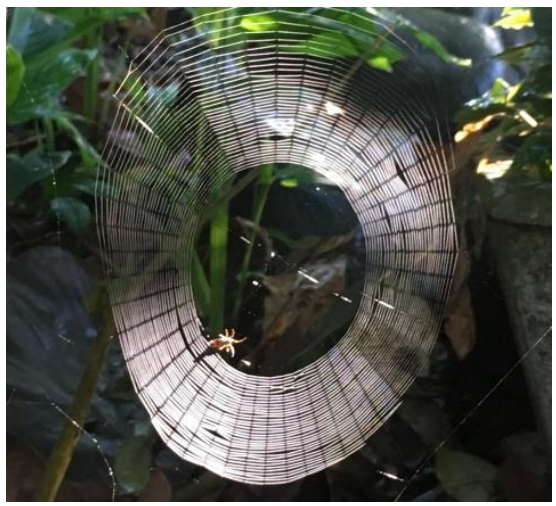

Gambar 16. Sarang laba-laba sebagai hasil kreativitas dan kecerdasannya Sumber: Dokumentasi Prawoto, 2016

\section{Form and Space}

Form and space juga bisa dipelajari dari alam. Alam memberikan bentuk dan ruang yang sepertinya tanpa batas, ada banyak sekali model bentuk dan juga model ruang yang bisa diambil. Mulai bentuk yang persegi sampai bentuk yang melingkar, bahkan yang tak beraturan pun ada di alam. Ada yang berupa garis, bidang sampai ruang. Ada juga yang berupa batang, lempeng dan juga pukal.

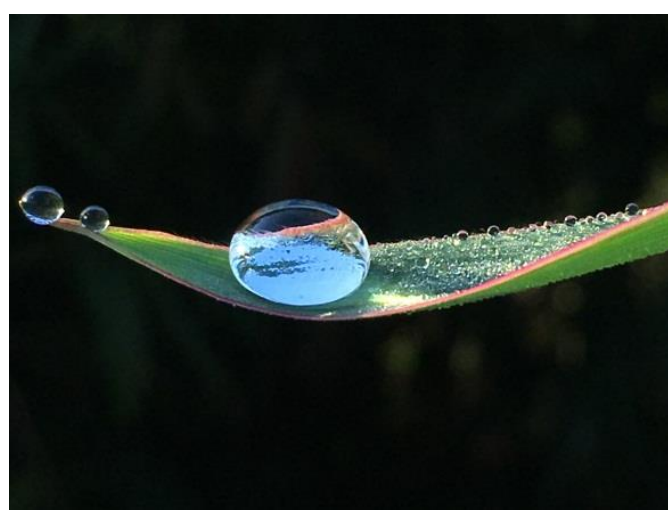

Gambar 17. Tetesan embun berbentuk bola pada sebuah daun

Sumber: Dokumentasi Prawoto, 2016 


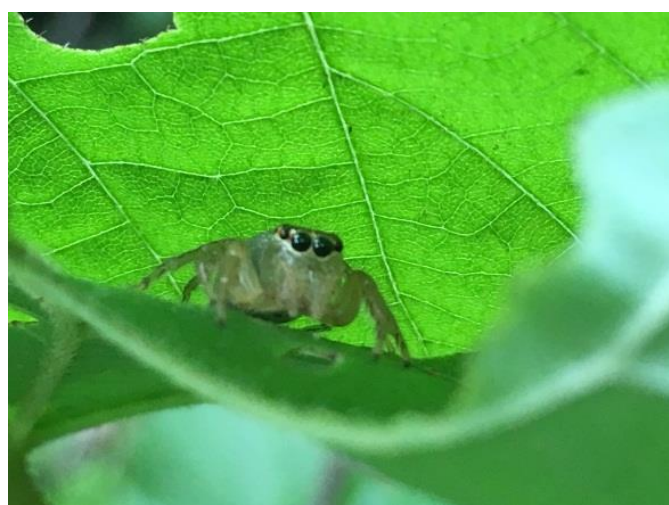

Gambar 18. Seekor katak menemukan spacenya diantara dedaunan

Sumber: Dokumentasi Prawoto, 2016

\section{Light and Darkness, Shadow and Shade}

Cahaya, mungkin menjadi syarat utama keberadaan manusia, paling tidak secara visual. Karena tanpa cahaya, kita tak akan bisa melihat indahnya dunia. Di alam, cahaya dan kegelapan menjadi pasangan serasi yang saling mendukung satu sama lain. Cahaya dan bayangan kadang membantu kita untuk meresapi sebuah peristiwa (bisa juga peristiwa arstektur), di mana kita bisa belajar berdialektika, bahwa unsur yang berlawanan adalah sebagai sebuah pasangan yang menguatkan keberadaan masing-masing.

Cahaya dan bayangan juga memperkuat kesan tiga dimensional, yang merupakan suatu hal yang harus "diselesaikan" oleh seorang arsitek supaya objek yang dirancang tidak sekedar objek yang datar dan mati, tetapi mampu menghadirkan objek nyata yang meruang dan "hidup".

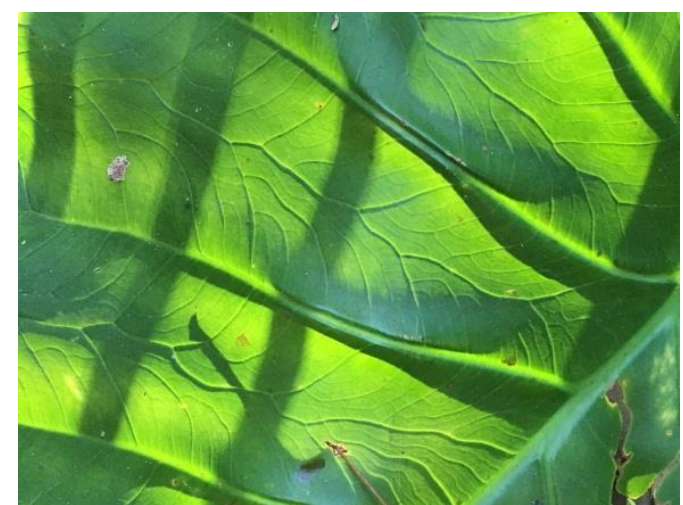

Gambar 19. Cahaya menghasilkan bayangan yang memperkuat kesan tiga dimensi pada daun

Sumber: Dokumentasi Prawoto, 2016

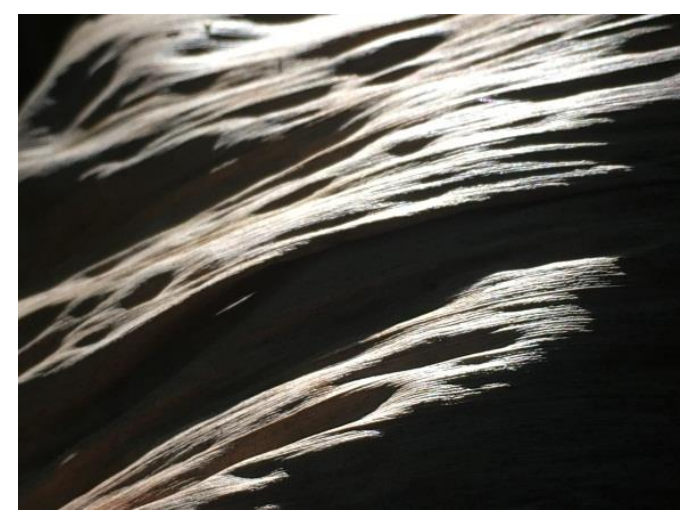

Gambar 20. Unsur gelap terang, shadow dan shade membuat kesan tiga dimensi pada daun pisang

Sumber: Dokumentasi Prawoto, 2016

\section{Semangat dan Nilai}

Semangat dan nilai kehidupan juga bisa kita pelajari dari alam. Yang paling dikenal mungkin lumut sebagai tanaman perintis, yang memberikan kita kesadaran bahwa kehidupan harus dijalani dengan semangat tanpa kenal lelah. Lumut yang remeh dan lembut itu ternyata mampu menghancurkan batu-batu yang keras menjadi tanah, yang sangat berguna bagi tumbuhnya tanaman yang lain (yang tumbuh berikutnya), dan nantinya juga akan berguna bagi makhluk hidup yang lain.

Tanaman kecil di antara batu-batu ini juga menunjukkan sebuah semangat 
yang kuat untuk menghadapi ganasnya lingkungan, yang kadang tidak bersahabat. Namun, tanaman kecil tersebut memiliki semangat di tengah keterbatasan itu, dan itulah yang membantunya untuk terus tumbuh menjadi semakin besar, sampai akhirnya bisa "menaklukkan" lingkungannya.

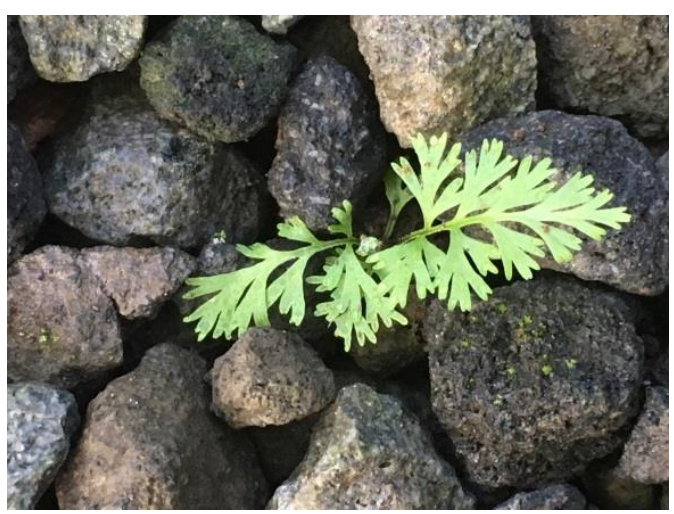

Gambar 21. Tanaman kecil yang berusaha tumbuh diantara bebatuan

Sumber: Dokumentasi Prawoto, 2016

Perjuangan laba-laba membangun sarang juga menarik. Ketika dirusak dalam proses pembuatannya, dia akan membangunnya lagi, mulai dari awal lagi. Tentunya, ketika membuat sarang, dia harus mempertimbangkan tempat yang strategis, agar sarangnya bisa menangkap mangsa sebanyakbanyaknya.

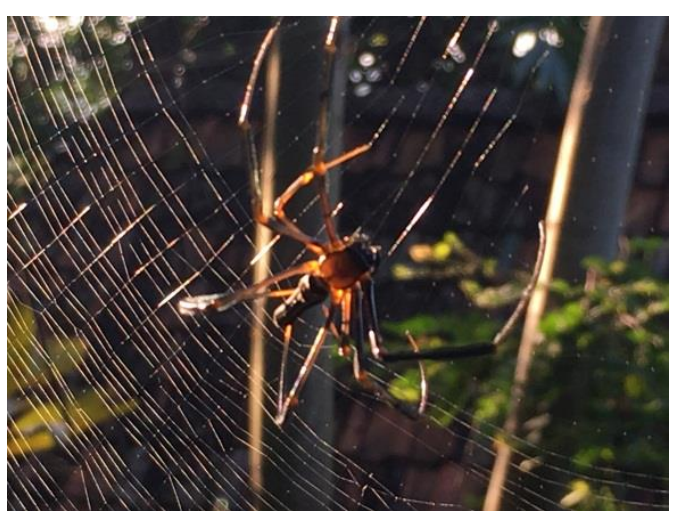

Gambar 22. Proses laba-laba dalam membuat sarangnya yang memerlukan "perjuangan"

Sumber: Dokumentasi Prawoto, 2016

\section{Arsitek Alam}

Di alam, ada banyak "arsitek" yang bagus, "tanpa nama" dan sangat sadar akan lokalitas, karena binatang yang membuat sarang, selalu memakai bahan yang tersedia di alam. Mereka pun sangat cerdas di dalam "menyiasati" sifat alam yang berprinsip siapa yang kuat, dialah yang menang.

Laba-laba yang membuat jaring menjadi salah satu contoh yang menarik. Bukan hanya tentang bentuk dan model jaringnya yang berkualitas maverick, tetapi jaring itu juga rumah sekaligus tempatnya mencari makan, karena jaring itu sebetulnya juga sebuah jebakan. Ini merupakan contoh bahwa arsitektur tidak hanya bisa dilihat dari satu sisi (monodimensi), tetapi bisa dilihat dari banyak sisi yang berbeda (multidimensi). Bagi manusia, sarang itu juga sebagai penanda, apakah ada orang yang sebelumnya melintas di situ.

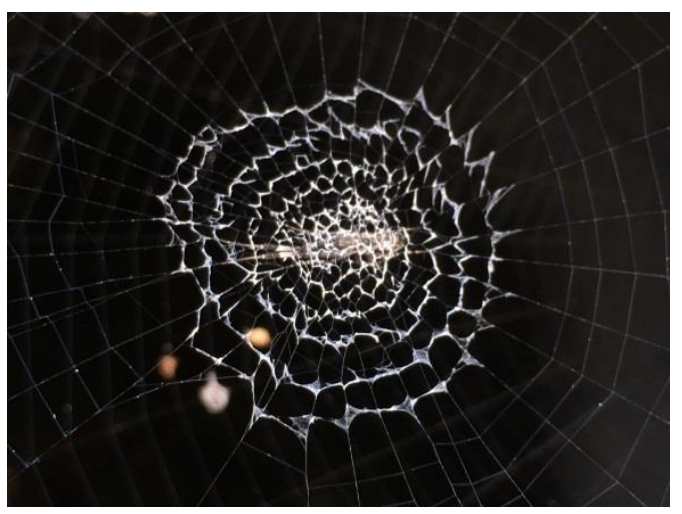

Gambar 23. Jaring laba-laba dengan bentuk dan model yang berkualitas maverick Sumber: Dokumentasi Prawoto, 2016 


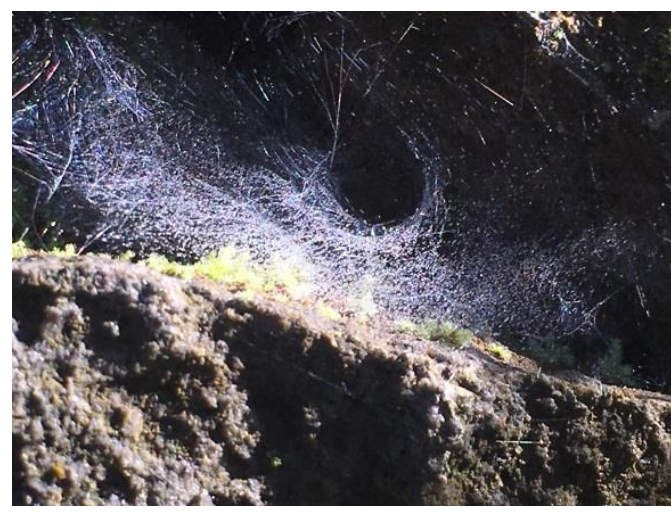

Gambar 24. Jaring laba-laba yang berkualitas maverick berfungsi sebagai rumah dan tempat mencari mangsa

Sumber: Dokumentasi Prawoto, 2016

\section{Tugas Studio untuk Mahasiswa Tahun Pertama}

Tahapan pembelajaran pada studio tahun pertama adalah tentang bagaimana melihat, mengapresiasi, menganalisis, memahami, lalu kemudian menggunakan atau mengaplikasikan pada desain.

Sebagai contoh pada tugas studio untuk mahasiswa semester satu adalah meditasi daun. Dalam pengerjannya, mahasiswa diminta untuk berjalan di kebun atau halaman dengan pelan-pelan dan tenang untuk memilih daun yang mereka anggap menarik. Lalu, mereka mengambil daun kering yang dipilihnya tadi dan kemudian mereka harus mengamati visualnya secara detail.

Tahap selanjutnya, mereka diminta untuk membuat sketsa dengan sangat detail dan membuat cerita berdasar pengalamannya dengan daun tersebut. Akhirnya, mereka diminta untuk sharing kepada temantemannya tentang pengalamannya tadi.

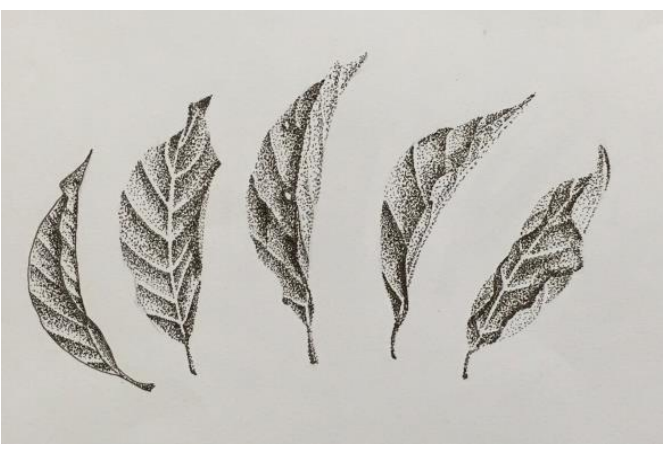

Gambar 25. Sketsa daun oleh Jameraldo C.T. Girsang (61170241)

Sumber: Dokumentasi Octavia, 2017

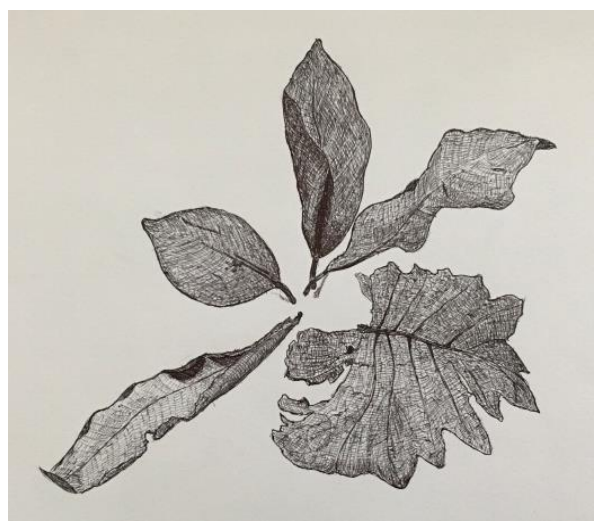

Gambar 26. Sketsa daun oleh Nelson (61170235)

Sumber: Dokumentasi Octavia, 2017

Tidak hanya secara visual yang dangkal saja, tetapi melalui daun ini mereka bisa mempelajari banyak hal, seperti: geometri, organisasi/ tatanan, struktur, tekstur dan warna, form and space, dan light and darkness, serta shadow and shade.

Contoh lainnya yaitu tentang merekam tekstur batu yang mereka temukan di halaman. Tahapannya kurang-lebih sama dengan meditasi daun, yakni mereka diminta untuk memilih batu yang paling menarik, lalu diamati teksturnya dengan sangat detail dan kemudian memindahkannya ke dalam bentuk sketsa.

Selain kemampuan (skill) untuk memilih dan mengambarkan objek alam, 
kesadaran dan rasa terhadap objek alam itu juga merupakan target dalam tugas ini.

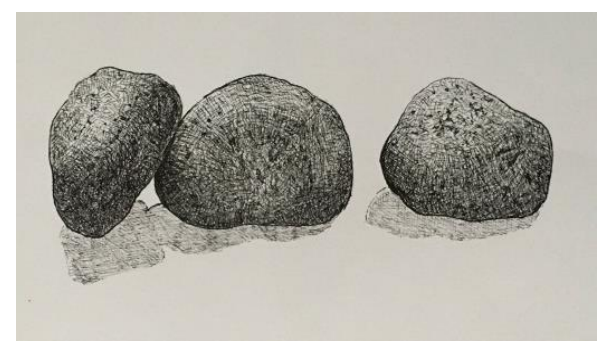

Gambar 27. Sketsa batu oleh Nelson (61170235)

Sumber: Dokumentasi Octavia, 2017

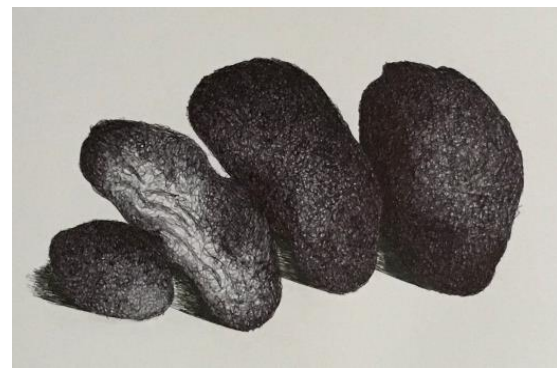

Gambar 28. Sketsa batu oleh Claudianny (61170256)

Sumber: Dokumentasi Octavia, 2017

Pembelajaran seperti ini di studio tahun pertama memang belum banyak diterapkan di sekolah-sekolah arsitektur. Metode ini mungkin akan terasa membosankan atau terlalu lambat, namun target dalam studio tahun pertama ini bukan hanya tentang kemampuan (skill) yang dimiliki, tetapi bagaimana menumbuhkan kesadaran dan rasa terhadap objek alam pada diri mahasiswa.

Kemampuan setiap mahasiswa tentu saja berbeda antara satu sama lain. Di sinilah peran pendidik sangat dibutuhkan untuk memanfaatkan dan mengembangkan kemampuan yang dimiliki setiap mahasiswa dengan cara menumbuhkan kesadaran sehingga mereka memiliki kepekaan yang lebih tajam dan keterampilan untuk berpikir secara kritis.
Semua potensi diri mahasiswa harus dikembangkan secara lebih optimal. Dengan demikian, studio tahun pertama ini menjadi sarana untuk mempersiapkan potensi dirinya. Pada akhirnya, mahasiswa dapat memahami alam sekitarnya dari interaksi dengan diri sendiri, dan juga melalui pertemuan dirinya sendiri dengan alam.

\section{Kesimpulan}

Dalam pembelajaran arsitektur, kita masih sering terjebak pada pembelajaran yang idealistik yang bersumber pada logika dan nalar geometri yang abstrak. Seakan-akan bentuk dan wujud arsitektur muncul dari pikiran/ kepala arsitek. Tetapi kita cenderung melupakan cara untuk belajar dari alam yang sebetulnya memberi kita sumber-sumber ide yang sangat kaya dan beragam dalam berarsitektur.

Bahkan, hal seperti ini (belajar dari alam) sebetulnya sudah dilakukan oleh nenek moyang kita dulu dalam berarsitektur dan menghasilkan karyakarya arsitektur yang luar biasa, yang tak kalah kreativitasnya dengan arsitektur masa kini. Namun, hal itu justru banyak dilupakan oleh generasi arsitektur masa kini yang malah berkiblat pada kesadaran yang antroposentris (berpusat pada manusia) yang menganggap alam sebagai objek belaka.

Maka dari itu, pada tahap pembelajaran awal untuk mahasiswa di tingkat dasar, perlu pengenalan yang lebih mendalam pada bentuk-bentuk dari kearifan alam, yang diposisikan sebagai "guru". Ini dengan pertimbangan bahwa kesadaran akan pelajaran dari alam itu nantinya akan terpatri secara kuat di benak mereka dan dipraktekkan dalam arsitektur 
secara nyata ketika mereka menjadi arsitek yang terjun di tengah-tengah masyarakat.

\section{Daftar Pustaka}

Mangunwijaya, Y.B. (1988). Wastu citra. Jakarta: PT Gramedia.

Uehiro, Eiji. (1998). Practical ethics for our time. Tokyo, Japan: Tuttle Publishing.

\section{Ucapan Terima Kasih}

Terima kasih kepada:

1. Fakultas Arsitektur dan Desain Universitas Kristen Duta Wacana yang telah memberi kesempatan untuk menerapkan metode ini di Studio Perancangan Dasar 1.

2. Anas Hidayat, S.T., M.T. yang telah membantu terselesaikannya tulisan ini. 